\title{
The Role of the Pamong Praja Police Unit in Increasing Regional Original Income
}

\author{
Gunawan $^{1}$, Zudan Arief Fakrulloh ${ }^{2}$ \\ \{gunawanigun221@gmail.com¹, cclsis@yahoo.com² \\ Program Doctor of Law, Universitas Borobudur ${ }^{1}$, Faculty of Law, Universitas Borobudur ${ }^{2}$
}

\begin{abstract}
The cash used to fund regional initiatives and profit-sharing between the center and the regions is known as regional original income. One of the responsibilities of the civil service police unit is to enforce local government policies. As a result, in addition to the relevant government agencies, the growth in local revenue plays a vital role in the civil service police unit implementing laws. This study employed either normative law with a model of action on specific legal events or normative-empirical law with case studies as an approach. The findings of this study show that the civil service police unit plays a pretty substantial role, given that counseling, operations, patrols, and monitoring are among this agency's key activities and functions. Satpol PP, on the other hand, faces numerous challenges in carrying out their obligations, not least in terms of staff and infrastructure, which have a population-toinfrastructure ratio of only 1:50. Because the civil service police unit's responsibilities are confined to taking action, there is no clear intention from the leadership to raise local revenue.
\end{abstract}

Keywords: Satuan Polisi PP; Pendapatan Asli Daerah; Tugas dan Fungsi

\section{Introduction}

The government formed the Civil Service Police Unit, which aims to help regional heads maintain peace, order, and order. The administration of the government can run smoothly, and the community can carry out activities safely [1]. The Civil Service Police Unit, abbreviated as Satpol PP, will be one of the Regional Government's tools for keeping peace and order and implementing Regional Regulations in the future. The Civil Service Police Unit's organization and operating processes are outlined in a Regional Regulation. Satpol PP might be based in any of the provinces, regions, or cities.

a. The Civil Service Police Unit in the Provincial Region is directed by a Head who reports to and is accountable to the Governor through the Regional Secretary.

b. The Civil Service Police Unit of a Region or City is commanded by a Head who reports to the Regent or Mayor through the Regional Secretary.

To realize the ability and independence of the region as well as to strengthen the structure of regional revenue, the contribution of PAD (Regional Original Income) in the design of the APBD (Regional Revenue and Expenditure Budget) must consistently be increased because it is one of the benchmarks of ability and a mirror of regional independence [2]. The lack of 
PAD revenue is still considered an obstacle. Each local government must seriously evaluate this to improve services and facilitation to the community. One of the things that has become the basis of the problem of regional income accomplishment so far is the lack of effective and efficient aims to realize the reality of addressing community demands.

Until now, the potential for local revenue has not been explored in general due to the lack of sensitivity of the local government in finding cultural advantages and potential local revenue (PAD), relatively low compliance, and awareness of taxpayers/retributions, weak legal system, and local revenue administration. The weakness of the apparatus, fears of the bureaucracy will fail in carrying out its program, not optimistic about the results that might be achieved. Suppose PAD can be optimized and managed professionally by discovering the advantages of local culture and potential and strong will from all stakeholders. In that case, it will grow competitive regional competitiveness and improve community welfare through propeople programs.

Regional original income, or in the future referred to as PAD, is revenue obtained by the region from local sources in its territory, which is collected based on local regulations under local regulations or applicable laws. Sector Regional income plays a significant role because through this sector, and it can be seen how far an area can finance activities government and local development. The sources of funding for the implementation of regional government consist of Regional Original Revenues, Balancing Funds, Regional Loans, and Other Legitimate Income. Regional Original Revenue is Regional Revenue derived through Regional Taxes, Regional Levies, Separated Regional Assets Management outcomes, and other valid Regional Original Income, with the goal of allowing regions to explore funding options as part of their autonomous implementation. The notion of decentralization is embodied by regions.

In the context of structuring and expanding the basis of Regional Original Revenue (PAD), mainly related to Regional Taxes and Regional Levies, the government has issued Law no. 28 of 2009 concerning Regional Taxes and Levies, in which there are some fundamental changes to Regional Taxes for provinces and Regency/City Regional Taxes. In this provision, the Regional Tax for the region consists of 1. Motor Vehicle Tax; 2. Fees for Changing the Ownership of Motor Vehicles; 3. Motor Vehicle Fuel Tax; 4. Surface Water Tax; and 5. Cigarette Tax. Meanwhile, Regional Taxes for districts/cities consist [3] of 1. Hotel Tax; 2. Restaurant Tax; 3. Entertainment Tax; 4. Advertising Tax; 5. Street Lighting Tax; 6. Tax on Non-Metallic Minerals and Rocks; 7. Parking Tax; 8. Groundwater Tax; 9. Swallow's Nest Tax; 10. Rural and Urban Land and Building Taxes; and 11. Fee for the Acquisition of Land and Building Rights.

The types of taxes that the Regions can levy must be under those stipulated in Law no. 28 of 2009. As for regional levies, with government regulations, there is still an opportunity to add other types of levies other than those stipulated in the law as long as they meet the criteria set. The chance to add classes of levies with government regulations is also intended to anticipate the transfer of service and licensing functions from the government to regions that are also regulated by government regulations. Article 1 paragraph (8) and Article 2 paragraph (1) of Government Regulation Number 6 of 2010 governing Civil Service Police Units define Satpol PP's role as law enforcement officers. In essence, the two articles declare that Satpol PP was established as part of the regional apparatus to help regional leaders in executing regional legislation and keeping public order. The role of Satpol PP to implement regional regulations and protect public order and public peace is further emphasized in Articles 3 and 4 of PP No. 6 of 2010 concerning Civil Service Police Units. For the sake of public order and peace, the 
Satpol PP is required to avoid using forceful methods in pursuing any charges and instead focus on persuasion.

Satpol PP members serve as local government officials who are occupied by civil servants and are assigned duties, responsibilities, and authorities in enforcing Regional Regulations and Regional Head Regulations, administering public order and peace, and protecting the community in accordance with laws and regulations. Satpol PP, on the other hand, is a regional apparatus established to implement Regional Regulations and Regional Head Regulations, preserve public order and peace, and provide community safety. Let's say there's an issue with taxes. In that instance, the Satpol PP will look into the problem, starting with the community depositing tax money to the kebayan. The cash to be sent to the Regional Finance Agency (BKD) office have been misappropriated. The payment has not been made.

The term "role" refers to something that is performed or played. A role is described as an action performed or performed by someone with a position or social status inside an organization. According to terminology, a role is a collection of characteristics that people who live in society are required to exhibit. The position is known in English as "role," which means "person's responsibility or duty in the effort. "A person's duty or obligation in a business or work," it signifies. The role is defined as a set of behaviors that people who live in society are supposed to have. At the same time, a role is a person's participation in an event. A role is a task that a person or an institution/organization does.

The role that an institution/organization must fulfill is usually governed by a stipulation that is a function of the institution. In this case, the Satpol PP carries out activities to increase PAD based on enforcing Regional Regulation No. 8 of 2018 concerning regional taxes. The amount of payment or what should be given to the hotel is the basis for imposing hotel tax in which it governs Article 6. Article 13 The amount of compensation received or expected by the restaurant is the basis for applying a restaurant tax. Article 18 The entertainment tax is levied on the service of providing paid entertainment. 55th Article The acquisition value of groundwater is used to justify the implementation of a groundwater tax.

\section{Methodology}

The normative-empirical technique employed in this study is legal examination of the enforcement or execution of normative legal provisions in action on every specific legal event that occurs in society (empirical facts) [4]. Normative-empirical legal research (applied law research) uses normative-empirical legal case studies in the form of legal behavior products [5]. The descriptive approach is a sort of research that aims to offer a complete picture of the social context or to investigate and clarify a phenomenon or social reality by describing a number of factors related to the problem and the unit under study between the study phenomena being tested.

Based on the source of data collection, researchers used primary data, namely data obtained directly from the object under study through data collection procedures and techniques in the form of observations, interviews, and other measurement instruments specifically designed according to the objectives of the researcher. Qualitative analysis was utilized to analyze the data in this study. Qualitative analysis is defined as a method of data selection that results in descriptive data. Secondary data that has been available as a basis for the research is connected with primary data, which includes the results of observations and interviews and then analyzed qualitatively. 


\section{Results and Discussion}

\subsection{The Civil Service Police Unit's Contribution to Regional Original Income}

The Civil Service Police Unit, also known as Satpol PP, is a regional apparatus established to implement Regional Regulations and Regional Head Regulations, preserve public order and peace, and offer community safety, according to PP No. 16 of 2018. Civil Service Police, or Pol PP, are members of the Satpol PP who work as local government officials and are given duties, responsibilities, and authorities under the laws and regulations in enforcing Regional Regulations and Regional Head Regulations, as well as administering and maintaining public order. Safety and security for the general public.

As a tool that carries out state functions, the government must act to represent the needs of the people. When it comes to government administration, the focus must be on providing the best possible services to the public. The government is regarded to serve the community, not to benefit itself, and to provide conditions that allow each community member to develop their strengths and inventiveness in order to attain common goals. Government performance in realizing good governance can be assessed from the ability to implement laws and regulations and the implementation of public services. Providing public services efficiently, effectively, and responsibly is a measure of good governance performance.

Satpol PP's participation in implementing Regional Regulations in Boyolali Regency is crucial since it has completed its basic mission, which is to help Regional Heads in carrying out government tasks in the areas of public peace and order and enforcement of Regional Regulations. It conducts operations with a stationary system, a hunting system (car), conducts routine and regional patrols, guards vulnerable places, and fosters traffic facilities. Operational activities of Satpol PP in enforcing local regulations in Boyolali are:

a. Operating activities (Patrols) in the area are carried out every morning, afternoon, and evening. The Satpol PP operational activities in 2020 are:

1. Concentration Operations (Community Diseases) is carried out once a week.

2. IMB Control Operations (building permits) are carried out once a month.

3. Operations to control advertisements are carried out once a month.

4. Control operations for street vendors (pedestrians) are carried out once a week.

5. Routine patrols against Perda customers are carried out regularly every morning, afternoon, and evening.

b. I was counseling the public regarding local regulations concerning the regulation of public interest. With the operation and counseling activities carried out by the Satpol PP, violations of the Boyolali District Regulation have decreased from year to year. This can be seen from the number of Perda violations that have entered the Boyolali Regency Satpol PP Office for the last three years (2018-2020).

In implementing Regional Regulations, the Boyolali Regency Satpol PP plays a significant role because they often carry out operations and outreach activities to the public about the Regional Regulation. Must comply with existing procedures. The operational procedures are: (1) Investments in violators of Regional Regulations or Perda, (2) Development with a humanitarian approach, (3) Summons or reprimands, (4) Coordination with related agencies, (5) Non-Justicia preventive operations or confiscation of goods, (6) Administrative equipment (letter of assignment), (7) Making minutes of taking an interest, (8) Operational activities carried out by the Boyolali Regency Satpol PP always involve related agencies or agencies, (9) The existing civil servants (including those at the Satpol PP Office) have not been 
inaugurated. Whenever there is an operational activity, the investigation is carried out by police investigators.

One of the sources of Regional Original Income (PAD) is the receipt of regional taxes and levies. Provincial taxes and levies are a form of community participation in supporting the implementation of regional autonomy. The problem faced by the Boyolali Regency Government in the effort to obtain provincial taxes and levies is that not all local taxpayers/retributions are willing to pay their obligations according to the provisions. They tend to avoid these obligations, for example, the construction of buildings without an IMB, the establishment of unlicensed business premises, placing advertisements or business advertisements that violate the provisions, and so on.

As a result, by better enforcing Regional Regulations and Regional Regulations, the Satpol PP can provide support to the Regional Apparatus Organizations (OPD) in charge of Licensing, namely the Investment and One-Stop Integrated Services Agency (DPMPTSP), as well as the OPD in order of Regional Revenue, namely the Regional Finance Agency (BKD) as well as all OPD, Work Units and BUMD that manage regional income. In practice, this OPD, Work Unit, and BUMD have not involved the Satpol PP in monitoring, controlling, and prosecuting Regional Regulations and Regional Regulations Violations, which impact the less than an optimal collection of regional taxes and levies. This happens because of the negative stigma on the Satpol PP and the poor working relationship between the Satpol PP and the OPD, the Work Unit, and the OPD.

This is reinforced by the results of an interview with Tri Joko Mulyono, Head of Enforcement, Satpol PP has the task of enforcing regional regulations; therefore, Satpol coordinates with relevant agencies or OPDs to be able to collaborate and work together in enforcing provincial laws related to violations in these regional regulations. . it can be concluded that to be able to carry out its authority, Satpol PP must have the trust and support of the relevant Boyolali Regency Apparatus Organization. Thus, it is necessary to have an innovative strategy to improve the image of Satpol PP.

\subsection{Obstacles in Supporting the Main Duties and Functions of Civil Service Police Units in Increasing Local Revenue and Their Solutions}

Government policies in implementing local regulations, especially in controlling street vendors, have become a problem in Indonesia, especially in big cities that are densely populated. Because this policy can harm the small business community in seeking their livelihood. Local government policies in controlling street vendors, especially vegetable, fruit, and food sellers, always involve the Civil Service Police Unit because they are tasked with implementing local regulations and regulations. As one of the people's economic businesses that carry out trade activities in the informal sector, street vendors have an essential role in supporting the regional economy to improve living standards and have the potential to become a regional tourist attraction.

In connection with peace and order conditions, both in terms of street vendors who sell on the sidewalk, it is necessary to guide peace and order in the area in a planned and integrated manner. In overcoming the threat of disturbance of peace and order, a system fostering peace and order is applied according to specific patterns, both through community and government efforts through the prosperity and security approach. But on the other hand, it is not uncommon when the Civil Service Police carry out their duties in controlling street vendors. It causes problems among the traders themselves. 
Hani Rulianto, the task executor in the field of Public Order and Community Peace, was interviewed. The involvement of Satpol PP in raising Regional Original Income through operations involving linked agencies, in this case, the Financial Agency Region, Pamiong Praja Police Unit, and Inspectorate, is very much needed.. Because there are many potential taxes or tax objects that are less than optimal in boosting Regional Original Income. Second, the obstacle faced by Satpol is that the main tasks of the Satpol PP are too many to divide the time between the main functions and functions with the intensification team.

Given the Satpol PP's responsibilities, particularly in the field as assistants to the Regional Head in the enforcement of Regional Regulations and the implementation of public peace and order, the Satpol PP must be responsive and capable of maintaining a steady and controlled state of peace and order. The notion of regional autonomy is used to carry out government obligations and powers in dealing with difficulties that arise as a result of globalization's overall impact. The decentralization or democratization of administration with direct participation of community members is at the heart of regional autonomy. This is a new dimension for the government to give broad authority to local governments with the hope that local governments can implement fair, democratic, and transparent governance in the public sector.

The presence of the Civil Service Police Unit in law enforcement (repressive) as a local government apparatus, in particular, necessitates Satpol PP's contribution to the successful implementation of Regional Autonomy. in the thick of community, as well as supporting law enforcement in the fight against all sorts of fraud. It is surely not as simple as turning the palm when it comes to carrying out the Civil Service Police's authority to enforce regional regulations and regional head decisions, which is one of the Civil Service Police's key functions. As a result, Civil Service Police officers frequently encounter a variety of challenges when dealing with persons who have vested interests in fighting for their life, resulting in disputes (clashes).

Control is carried out in the Boyolali Regency area, which is dominantly interested in Street Vendors. The Boyolali Regency Government needs to design a program for handling the empowerment of Street Micro, Small, and Medium Enterprises (MSMEs) to act humanely without violence and injuring, but empowering optimally in the hope of creating an area clean, beautiful, orderly, and prosperous. First and foremost, we must focus our attention on the legislation governing the Sat Pol PP, namely Government Regulation Number 16 of 2018 concerning Guidelines for the Civil Service Police Unit, in order to understand the task and function of the Sat Pol PP, particularly in fostering and enforcing the law.

With the issuance of this Government Regulation, it is hoped that various organizational confusions, duties, and functions, as well as other things that become the attributes of Pol PP, which have been constructed differently at the province and district/city levels, can soon be uniformed in carrying out their authority to impose legislation. Regional Heads and Regional Heads' decisions, as one of Pol PP's key responsibilities, are far from simple, especially when it comes to carrying out their authority. Non-judicial repressive powers are a limit to pol PP. As a result, Pol PP personnel frequently encounter a variety of challenges while dealing with persons who have vested interests in fighting for their life, resulting in disputes (clashes).

In reality, on the ground, the enforcement of Regional Law Products concerning public order and peace will intersect with the interests of the general public. On the one hand, there are still many things and community activities that are colored by violations. Still, the breaches themselves are not felt by the violators. Even people who violate them tend to believe that their actions are not violations, even though rules regulate them. In addition, the enforcement of regional legal products concerning peace and public order by the Civil Service 
Police Unit is still colored by things that are not under legal provisions and public expectations, for example, the demolition of street vendors who seem arrogant, releases and confiscations. Advertising/advertising promotion media without starting with a warning to the installer, there are still Satpol PP officers who carry out illegal levies, and so on. Therefore, until now, the public perception of the existence of Satpol PP is still not good, or in other words, the image of the Civil Service Police Unit (Satpol PP) is still negative in the community.

The arrangement of street vendors is not yet a package with a solution to have the impact of excessive unemployment and reduced employment. The operational facilities of Satpol PP include limited fleets and communication tools, with a ratio of 1:50 in the implementation of the arrangement of Street Vendors. People who start trading are primarily unlicensed and are always volatile when agreements are made. Satpol PP is always based on regional regulations, so the target is always detrimental to the community. The district government should use the principle of a win-win solution.

Implementing law enforcement cannot be carried out properly because people think that law enforcement officials have not implemented sanctions against them, so they can still do what they have done so far. When they occupy the location of their performance, Street vendors never intend to apply for a trading license. When the Boyolali City Government was about to organize it, they objected to asking for dialogue and dared to oppose the government. The Satpol PP in organizing is always based on the Regional Regulation so that the target is always detrimental to the community. The implementation of the arrangement should be accompanied by solutions, such as the provision of cart assistance, relocation, shelter assistance, and so on. For example, a raid and action must be taken to be ready and comply with the existing rules.

\section{Conclusion}

The Civil Service Police Unit in Boyolali Regency is in charge of enforcing regional regulations. The Satpol PP's function in enforcing regional regulations is carried out by carrying out operational activities such as operations with a stationary system and processes with a car system. (hunting), conducting routine patrols against violations Regional Regulations, guarding places prone to breaches of Regional Regulations, conducting regional patrols, sending Civil Service Police personnel in technical and functional training, coaching and technical approaches for Civil Service Police personnel and counseling the community on Regional Regulations. HR factors, both in terms of communication skills and approach, as well as the number of members of the community who are unaware of and unwilling to cooperate with Satpol PP to control street vendors, and a lack of socialization to the community, are all obstacles to Satpol PP carrying out its duties and functions.

\section{References}

[1] S. Syarif and S. Suparno, "Legal Ideal of Pancasila on Legal Politic in the Formulation of Laws and Regulations," 2021, doi: 10.4108/eai.6-3-2021.2306458.

[2] M. Kurdi, D. Kurniawati, V. Andrianingsih, A. Furqani, N. Alfiyah, and M. Arifin, "The Government's Role in MSMEs Development Through E-Commerce in Sumenep Regency," 2021, doi: 10.4108/eai.6-3-2021.2306388. 
[3] M. Timur, A. Pradhanawati, H. Purnaweni, and K. Kismartini, "Policy Analysis of Socio-Economic Development of Coastal Areas in Central Java Province," 2021, doi: 10.4108/eai.9-10-2020.2304711.

[4] J. J. Little, "Cognitive load theory and library research guides," Internet Ref. Serv. Q., vol. 15, no. 1, pp. 53-63, 2010, doi: 10.1080/10875300903530199.

[5] J. D. I. Duncan and J. D. I. Duncan, Methodological Approaches. 2020. 